\title{
Ciência e consciência, conhecimento e liberdade
}

\author{
LUIZ ROBERTO ALVES
}

\section{Introdução: o espírito do tempo}

“...os átomos do Sol dialogam com os átomos dos olhos por meio da linguagem da luz, e a razão pela qual enxergamos reside nessa identidade de natureza entre o detector e o receptor".

(Morin \& Cassé, Filhos do Céu)

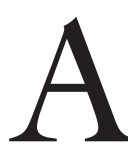

SSUMIDO como ensaio, este texto provê a releitura de um movimento crítico da ciência e da filosofia no século XX, com destaque para o período entre 1929 e 1969 cujo campo semântico evidencia gestões radicais da economia, guerras quentes e frias, ditaduras e proposições de nova humanidade. Centra-se em leituras da sociedade e do pensamento ocidentais com a certeza de que há ampla comunicação entre ideias, atitudes e conceitos de filósofos e cientistas cujo trabalho intelectual forja consciência, sob liberdade e com vistas a dar respostas frente a necessidades e desejos dos indivíduos e organizações da sociedade. A atitude dedutiva exigiu leituras intensas de ciências físicas, ciências sociais e filosofia, a partir de uma hipótese: um pensamento preponderante do entre e do pós-guerra do século XX teria criado uma necessária ruptura epistemológica para fazer convergir saberes e atitudes filosófico-científicas a favor de um conceito quase impensável em tempo de conflito, competição e disputa de hegemonia, a saber, o bem público. Convém lembrar que, desde a declaração dos direitos humanos, que contém certa universalidade do que é humanamente comum e público, somente em 2002, com o texto da ONU, o mundo conheceu uma discussão vigorosa sobre o bem-comum. ${ }^{1}$ Nesse ponto, encontram-se a relevância do tema e a atitude metodológica, pois essa hipótese engendra um sistema dedutivo pelo encontro de discursos que acumulam - contemporaneamente - valor de ruptura. ${ }^{2}$ Aqui, outra posição deste ensaio. Não se trata de uma descontinuidade ao modo das rupturas estéticas, como em Marcel Duchamp ou Andy Warhol, a qual cria programas individuais, a favor de uma personalidade estética única. Trata-se da clara consciência do desencanto de sociedades que, em suas disputas intestinas e internacionais, tanto se tornam mais injustas internamente quanto são incapazes de criar organizações saudáveis e ficam a derivar entre ideologias de grupos de poder. Irracionalizam-se. A tomada de consciência construiu um significado: o conhecimento deveria ser gerido a favor das maiorias (grandes vítimas das crises e disputas) e entendido como bem-comum. 
Sua gerência, portanto, somente seria possível no interior de um ente inequívoco: a sociedade democrática, aberta e pacífica.

Um dos sinais mais evidentes da virada científica da modernidade foi a análise de Bronowski (1979, p.9) diante do centro destruído de Nagasaqui. A serviço da Unesco, o cientista polonês desce do navio americano ao som da popular canção "Is you is or is you ain't ma baby" $\mathrm{e}$ se encontra com "os esqueletos dos edifícios das fábricas da Mitsubishi, como se mão gigantesca os tivesse empurrado para trás e para os lados". A bomba, fruto da ciência e de seus desdobramentos tecnológicos, caíra ironicamente sobre a maior população cristã do Japão e matara 40 mil somente nos primeiros instantes da eclosão. Bronowski não moraliza o fenômeno, nem discute culpas, pois outras armas haviam matado muitas outras pessoas na história e, na linha desse raciocínio, Maxwell poderia ter-se arrependido de dar à luz a televisão, bem como Oppenheimer morrido de remorsos pela fissão nuclear. O que de fato acontecia é que o uso repetido do novo arsenal de morte implicaria a atrofia do pensamento e o completo desnorteio quanto à missão da ciência, a busca da verdade, não somente no interior humano, mas no movimento de correlação entre fatos e conceitos de homens, natureza e artefatos. Tratava-se de celebrar a paz com as revoluções científicas, quer a do século XVI, que pusera a Terra em posição mais humilde no sistema do mundo, ligando Galileu a Da Vinci, quer a de John Dalton, 1808, que estabeleceu que o ato de fusão física é um ato criador, ou a de Einstein, que chama à compreensão de qualquer ciência como ato coletivo, movimento não só de fragmentação positivista, mas dos encontros que edifiquem projetos comuns. Bronowski (1979, p.63-76) completa: "não haveria Astrofísica, História, ou sequer Linguagem, se o homem fosse um animal solitário [...] Os homens exigiram liberdade, justiça e respeito precisamente à medida em que o espírito científico se espalhava entre eles".

Ainda próximo à Primeira Guerra Mundial, Weber (2002, p.37-58) também discute ciência e política. E o faz ao modo que conhecemos bem, em sala de aula. Ali, escancara toda a sua visão instrumental de ciência positiva. Mas o faz com profunda sinceridade. Depois de passar pela inteligência helênica, criadora de conceitos, e de concordar com Tolstoi, para quem a ciência moderna não teria sentido porque não responderia a duas questões-chave: Que devemos fazer? e Como devemos viver? O fundador do Archiv für Sozial Wissenschaft realiza várias comparações com a arte, a história e o direito. Levanta uma pergunta similar para os três saberes. Segundo Weber, a arte não pergunta se deveria haver obras de arte, pois em seu âmbito elas são criadas e fruídas; a ciência jurídica não responde à pergunta se deveria haver um direito, mas estabelece regras e métodos de interpretação jurídica segundo tempos e espaços sociais; assim também as ciências históricas não perguntam se os fenômenos históricos mereceriam existir e, ao contrário, tratam de compreender os fenômenos políticos, artísticos, literários e sociais. Desse modo, Weber vai destilando suas convicções, 
sempre polêmicas, mas precisas. Reconhece que o grande mal contemporâneo é "a fraqueza de não ser capaz de encarar de frente o severo destino do tempo presente". Em seguida, nega ao cientista qualquer direito a ser profeta, ou salvador. O seu cientista é somente um explicador, mas sua explicação não é desprezível, pois pode levar o interlocutor a reconhecer sua condição no mundo, a quem serve, de quem depende e talvez como libertar-se das amarras sociais. Nesse ponto, Weber associa o pensamento científico à "disciplina especial da filosofia", bem como "a metodologias de outras disciplinas", isto é, cria conexões entre diferentes atitudes científicas, basta que estejam todas elas a serviço do esclarecimento e da demonstração dos fenômenos da vida. Há um momento da reflexão weberiana, pouco trabalhado, que é o encontro com um pensamento mais tarde desenvolvido por um especial frankfurtiano, Walter Benjamin (1985). Aquele afirma que o tempo super-racionalizado do presente baniu valores sublimes e supremos, que se refugiaram na alma religiosa. Ele não explica plenamente se lastima ou aprova o fato, mas preocupa-se com as ondas de religiosidade do seu tempo e seus perigos. Benjamin, em raciocínio com maior base linguística, viu as forças místicas se homiziarem na linguagem, depois de expulsas das relações políticas. ${ }^{4}$ Weber termina proclamando que o cientista - bem como o professor - terá de ser um estoico explicador da realidade. A ciência não tem o dom de salvar, mas de clarificar os fenômenos da vida. É necessário, diz Weber, responder às exigências de cada dia.

Os fenômenos da vida se organizam como fatos semiológicos e mesmo linguísticos. O esforço de humanização do pensamento científico e a negação de sua atrofia, vistos em Bronowski, rebatem na racionalidade instrumental de Weber. Os rituais da violência devem ser contidos pela intermediação de uma atitude científica que, enquanto explica, produz consciência e comunica sentidos novos para a experiência humana. Nisso não se opõem os atores até aqui trabalhados. Ao contrário, trata-se de afinar uma linguagem nova, capaz de fazer ver onde estamos, diante de quais dilemas, obedecendo a quais contingências e em face de qual destino. Ora, os mais destacados homens e mulheres de ciência, que conviveram com o espectro das guerras da primeira metade do século XX, quer por via do instrumental funcionalista, quer por um existencialismo dialético, trataram de formular inter-relações de saberes a serviço do esclarecimento dos fenômenos, ou da intervenção do conhecimento na reversão do fado, do destino.

\section{A linguagem e o espírito do tempo}

Nesse processo, vai-se ao encontro de Lévi-Strauss e Roman Jakobson (1974), antropólogo e linguista. Depois da experiência entre os bororos brasileiros e da escritura dos textos básicos de etnologia, no Museu do Homem de Paris, Strauss concebeu que seria possível aos homens superar preconceitos, estereótipos e rivalidades desagregadoras da vida social, tanto pelo espelhamento dos sistemas de vida, capaz de superar a dicotomia civilização versus barbárie ou 
primitivismo, como pela aquisição de valores universais hauridos na competência linguística, os quais apontavam para os processos “primitivos” de integração e participação. No seu Anthropologie structurale, Lévi-Strauss (1958, p.95ss) faz evidente esforço para construir uma ciência total da comunicação, na qual se juntariam a antropologia social, a economia e a semiótica. Isso porque o cientista hoje centenário entendeu a sociedade como transversalizada por três processos, todos comunicativos: a comunicação de mensagens, a comunicação de bens e serviços e a comunicação dos pares sexuais. Para ele, afora o nível estratégico pelo qual indivíduos e grupos buscam situar-se no universo comunitário, os processos de comunicação construíam toda a vida social. Jakobson (1974, p.567) associa-se aos estudos de Turgot, Adam Smith, John Law e Ferruccio Rossi-Landi, que trataram como linguagem as diversas vertentes das organizações sociais, especialmente suas relações de uso e troca, os artefatos de distribuição da economia, a metalinguagem do poder e do mando e a estrutura de serviços organizada como fala e escritura. O dinheiro como mensagem. Noutras palavras, as estruturas sociais correspondem às estruturas da linguagem e o que excede a dimensão verbal é acolhido na ciência mãe, a semiótica. Desse modo, o rigor linguístico-semiótico faz-se modelo metodológico para as ciências humanas e sociais. Rossi Landi (1968, p.62) anunciara que "A economia no sentido próprio é o estudo do setor da comunicação não verbal que consiste na circulação de um tipo particular de mensagens habitualmente chamadas 'mercadorias'; para empregar uma fórmula mais breve: a economia é o estudo das mensagens-mercadorias". Parsons (1967, apud Jakobson 1974, p.57) já dissera que o dinheiro é uma linguagem extremamente especializada, que as transações econômicas equivalem a certos tipos de conversações e que a circulação monetária opera no sistema de envio de mensagens. Acrescente-se que no atual tempo cibernético dos capitais o fenômeno somente aguçou e se problematizou no movimento especulativo.

Embora ainda distantes dos trabalhos da nova microbiologia sobre o genoma, que é a linguagem celular em movimento contínuo, antropólogos e linguistas já conheciam os processos de decifração do DNA. Jakobson cita Crick e Yanofsky, que trabalharam sobre as moléculas do ácido nucleico e encontraram ali as mensagens moleculares codificadas, o que significa a existência de sequências lineares de palavras do código; as bases nucleotídeas são letras de um alfabeto que se abre à decifração, levando a uma extraordinária metalinguagem científica. Como ocorre na linguística, também na genética as unidades mínimas discretas são, em si, desprovidas de sentido, visto que a significação dá-se no sistema combinatório, cujo desenvolvimento no interior dos vários códigos culturais leva à análise dos discursos sociais e dos discursos naturais do DNA ou do sistema genômico. Efetivamente, a linguagem é a infraestrutura dos sistemas culturais. Um $b$ é somente um sinal discreto até que um sistema cultural lhe garanta referência (que o distingue de $a$ ou g) e ele se defina como um conjunto de significante e significado. Então, o $b$ significa. 


\section{Os encontros: consciência no tempo}

O esclarecimento desejado por Weber, que arrancasse as pessoas e grupos sociais do fado e da desorientação, especialmente em razão do que ele entendeu como "desencantamento do mundo", compõe uma linguagem científica associada a saberes estético-artísticos (conforme propugna Bronowski) que organiza um Zeitgeist, uma espécie de espirito do tempo no contrastante século XX. Tratou-se de pensar que seria possível universalizar valores e projetos homologamente à construção da consciência da solidariedade universal, o que seria simbolizado na linguagem e na cultura. Dos escombros das guerras quentes e frias poderia nascer um mundo re-encantado. Nesse movimento de ideias e conceitos em processo de apreensão, os cientistas recebem sinais dos filósofos, independentemente de segui-los. A obra marcante da dupla Sartre \& Ferreira (1971, p.14-17;118), parte da fenomenologia e chega a um sentido maior de liberdade e construção de consciência. Entre perguntas dramáticas, como os usos da fissão nuclear, o lançamento de foguetes e a produção/reprodução tecnológica, a obra franco-portuguesa recupera o projeto husserliano de "converter os dados da experiência no objeto do conhecimento", o que levaria a "pensar em segurança", visto que "toda consciência é consciência de alguma coisa", e chega a um projeto de liberdade que influencia toda a época, entre guerras e pós-guerra, ou seja, de que "a liberdade é coetânea da consciência, é o seu modo de ser". Portanto, diz Ferreira: "A liberdade não é uma qualidade que se acrescente às qualidades que já possuía como homem: a liberdade é o que precisamente me estrutura como homem, porque é uma designação específica da própria qualidade de ser consciente, de poder negar, de transcender" (ibidem). Husserl (in Lacoste, 1998) havia advertido sobre "as imensas dificuldades que barram o acesso a esse novo mundo" (que são os hábitos de pensamento reinantes) e Merleau-Ponty (in Lacoste, 1998, p.161-2) ajuda a sedimentar o sentido de consciência quando afirma que "parece a princípio verdadeiro que a consciência só pode encontrar em sua experiência o que ela própria ali colocou". A consciência não sabe tudo de antemão, mas no processo comunicativo reorganiza pensamentos anteriores e produz significações novas, atingindo a melhor compreensão do objeto que despertou o ato de pensar. Há, pois, um espírito geral: o direito intrínseco à liberdade, sinal evidente de consciência, um processo de comunicação em que os novos artefatos criados desafiam o conhecimento e exigem decifração linguística, a busca incessante de pensar com segurança para, talvez, não levar a humanidade a novos desastres. Tanto Bronowski quanto Weber, Lévi-Strauss/Jakobson e Sartre/Ferreira, ao se insurgirem contra o suposto fado sócio-humano - sinalizado nos fatos que vão de 1910 a 1950 -, manifestam e sugerem uma nova esfera de comunicação social, tanto universal quanto consciente da urgência na construção da humanidade liberada. Essa visão supera o partidarismo, o nacionalismo e o cientificismo. De fato, no seu interior movia-se um sentido inovador de gestão do conhecimento, indispensável para uma nova etapa do desenvolvimento humano. 


\section{Ecos na sociedade emergente}

Num debate sobre as visões de homem, Muraro (1968) advertia que a construção do mercantilismo capitalista e a forja das nações caminharam a passo com a informação visual e as comunicações especiais (jornal, folhetim, rodas mecânicas, livro, estradas de ferro), mas não sem a revolução religiosa, cuja marca luterana provoca certa humanização, que faz o homem encontrar-se com as realidades terrenas. Nos desdobramentos eletroeletrônicos, que propiciam os novos e espetaculares artefatos contemporâneos, tem-se também a forma da guerra: lenta e fragmentada nas fases mecânicas; global na idade elétrica e global e instantânea na idade da automação. Daí os traumas e as neuroses. Daí as mudanças de escala necessárias para a sobrevivência. Na construção dessa linguagem, Muraro (1968) cita Norbert Wiener (1894-1964), pai da cibernética, em epígrafe:

A primeira revolução industrial consistiu na desvalorização do trabalho muscular humano pela competição com o da máquina. Hoje em dia nenhum escavador manual pode competir com uma escavadeira mecânica. A atual revolução industrial está igualmente desvalorizando o trabalho cerebral humano, por enquanto nas suas funções mais repetitivas e rotineiras. [...] A resposta para esta situação é construir uma sociedade baseada em valores humanos ao invés dos valores de compra e venda. Para que possamos chegar a esta sociedade precisamos de uma grande dose de planejamento e de luta, que, na melhor das hipóteses, deverá travar-se no plano das idéias. Mas, se isso não acontecer, quem poderá saber o que acontecerá?

Ao mesmo tempo que se realiza a segunda revolução industrial do Brasil e sua consequente modernidade incompleta, pujante em acúmulo tecnológico e desigual em distribuição de bens, trabalha-se por uma cultura que eleve os padrões do saber geral e afirme valores de uma liderança educada e competente para o novo ciclo histórico. O educador clássico Azevedo (1963), em sua cruzada contra a proliferação de escolas superiores exclusivamente voltadas às letras, à história e à pedagogia, mostrava que os grandes embates contemporâneos residiam no campo das ciências e das técnicas; urgia, pois, o desenvolvimento do espírito crítico e experimental, não somente no chamado nível superior de estudo, mas especialmente na escola pública primária e secundária. Chamava a atenção do poder público para a empreitada, pois não via na iniciativa privada senão a busca do lucro em atividades mercantis e industriais. Azevedo faz lembrar Bronowski, pois considera que é precisamente o espírito científico, ao penetrar no processo social de conhecimento, o responsável por colocar a questão do humanismo, dos direitos cívicos. Humanismo não pode ser adjetivado, científico ou letrado. Ele é. Efetivamente, não se pode falar de humanismo fora de uma educação profunda: caráter, sensibilidade, consciência, coração. Enfim, o educador faz sua profissão de fé, precisamente no início de uma década que alterna, não sem conflitos, democracia e ditadura, desenvolvimento e desenvolvimentismo, concentração e desconcentração de poder, organização de sistema econômico e organização de redes sociais. Para ele: 
É certo (e nunca é demais insistir sobre esse ponto) que o tipo de homem de que necessitam as sociedades atuais é o homem de profissão (Berufsmensch), o cientista, o técnico, o especialista, que vale pelo que faz ou é capaz de fazer, isto é, pela sua eficiência (Leistung), pelo rigor de suas técnicas de ação, pelo seu poder criador ou pelo seu espírito inventivo. Mas o homem, para mim, vale também pelo que é, por sua sensibilidade, retidão e finura, por sua alta concepção de vida moral, por seus princípios, pela fidelidade às suas convicções, pela coragem de atitudes, por seu amor à verdade, à liberdade e à justiça. (ibidem, p.302)

Azevedo não crê, como Weber, que o intelectual educador deva salvar ou redimir os estudantes. Mas é mais animado a respeito da educação que o pensador alemão, pois os verdadeiros educadores “imprimem marcas inapagáveis" (ibidem, p.304) na memória de seus educandos, sendo atores de contínuo diálogo, como se dava com Platão, Sócrates e Aristóteles. No entanto, reconhece Azevedo, as salas de aula contemporâneas são precárias e lotadas, o que não invalida (ao contrário, reforça) a postura humanista, mas dificulta. Pior, no entanto, é que o magistério vai perdendo a sua capacidade dialógica diante da "tendência instigada ainda pela preocupação de reunir títulos e fazer carreira, escrever, amontoar trabalhos..." (ibidem, p.304).

\section{Proposições: ciência, desenvolvimento e liberdade}

Para introduzir o pensamento de Leite Lopes, ${ }^{5}$ vale a longa citação de Guerreiro Ramos, feita em obra de sociologia crítica e não de administração. No entanto, fazê-lo implica valorizar ainda mais a administração, porque o discurso científico mais aberto cria o estofo no qual trabalha o espírito teórico em busca de uma linguagem adequada para a ciência aplicada às organizações sociais. Em capítulo no qual discute a evolução da sociedade brasileira, entre nacionalismos, xenofobias, dependências e esforços a visar autonomia, Guerreiro Ramos (1957, p.51) considera que o país não tinha pautas institucionais para construir seu projeto de nação. Nessas ausências, grupos e facções trataram de encontrar fórmulas feitas, as quais eram impostas segundo propósitos e interesses de grupos de plantão no poder. Conclui o capítulo:

A sociedade brasileira, integrante que é da periferia da chamada civilização ocidental, não pode furtar-se à influência cultural das sociedades dominantes nesta civilização. Este condicionamento cultural, estreitamente vinculado ao imperialismo econômico, só é neutralizável quando são atingidas condições objetivas determinadas que apenas recentemente se configuraram em nosso país. (ibidem)

Por certo o autor de Administração e contexto brasileiro tinha algumas condições objetivas a apresentar nesse tempo da segunda revolução industrial do Brasil. Via a passagem do semicolonialismo para a emancipação (como os intelectuais do século XVIII trataram de ver o fim do feudalismo), via o reconhecimento de incipiente cultura de gestão, capaz de abrir brechas na burocratização modelada pelas facções dominantes, e via como possível criar novas competências humanas baseadas no mérito e em novo sentido de desenvolvimento, 
jogando para trás os fantasmas do racismo, do direito senhorial, da negação aos direitos modernos, como educação, cultura, trabalho digno.

Aí se prepara Leite Lopes. Citá-lo ao lado de Guerreiro Ramos provoca o arrepio do plágio. Não será, porém, plágio e sim o que se persegue, como método, neste ensaio: o espírito do tempo, indutor de um modo de gerir o conhecimento a serviço da sociedade nascente no pós-guerra. A par disso, a afinidade linguística, suporte do pensamento. Ao discutir ciência e desenvolvimento, tem-se:

permanecem os povos subdesenvolvidos, e as reservas e riquezas de seus países, à mercê dos povos desenvolvidos, até que forças e condições favoráveis surjam nos primeiros, capazes de estabelecer estruturas adaptadas a um desenvolvimento que tenha significação social e autonomia política, isto é, sem as características antigas ou modernistas, de dominação e exploração colonial. (Lopes, 1969, p.14)

Asserção comum, detalhes ímpares. Leite Lopes acrescenta que a ação colonizadora está presente no seu tempo. Nisso concorda com Furtado (1984), Schwarz (1994) e demais estudiosos da modernização dependente, que viram no estatuto colonial competência para imiscuir-se no coração da modernidade, ressemantizando discursos de antes pela roupagem do novo e, assim, capaz de manter formas simétricas de poder no antes e no hoje da sociedade. Embora não usem terminologia homológica, os diversos autores desse tempo de ruptura epistemológica em face do colonialismo concordariam com Schwarz (1994, p.2), que sugere ao movimento de ideias a "desprovincianização do pensamento". Schenberg (1968, p.87-93) entrara no debate ao afirmar que o século XX começara em 1914 e sua primeira metade concluíra por volta de 1960. Nesse tempo, discute Schenberg, os investimentos em tecnologia não podem ser senão grandiosos (por exemplo, petróleo, siderurgia e área hidrelétrica), o que separa povos desenvolvidos de subdesenvolvidos. Mais problemático, porém, é a formação de modelos:

Todo o nosso pensamento tecnológico foi formado tendo por modelo a Europa e os EUA, não levando em conta certas realidades [...] Nem sempre as soluções tecnológicas são de interesse do país. [...] Muitas vezes há uma supermecanização que não nos interessa. A supermecanização exige um capital que, como se viu, não temos. Precisamos apelar para um processo de desenvolvimento que combine os fatores de produção. (ibidem)

O texto que fecha a reflexão de Schenberg é precioso para o escopo deste ensaio:

O que presenciamos hoje no Vietnã é a presença de um poder material esmagador de um lado, derrotado por uma organização superior do outro lado. E aqui tocamos num ponto fascinante. Para Toynbee, a humanidade já superou a era tecnológica e entrou na era organizacional. E os problemas de hoje são os organizacionais. (ibidem)

Por fim, a esperança viva do cientista-mecenas. Ao tratar dos povos que emergem do subdesenvolvimento, vaticina: "Conhecendo a experiência passa- 
da, não incorrerão em erros (como a produção excessiva de objetos), mas darão ênfase em investimentos mais diretamente relacionados à vida e organização humanas". Quem dera!

\section{Reduzir a ilusão $=$ criar saberes}

Leite Lopes (1969) elabora suas propostas sob constatações similares. Trabalhava a favor de um país dependente, cuja inteligência propunha comprar os objetos tecnológicos dos países desenvolvidos, no qual abundava a ignorância dos modos de gerência organizacional dos bens, aliada à falta de visão sobre os novos modos de influência e ampliação da dependência, que se dão "menos por vice-governadores e tropas de ocupação do que pelo conhecimento científico..." (ibidem, p.25). Enfim, a ausência de novos e produtivos métodos de educação para a criança e a juventude reais do Brasil e dos demais povos latino-americanos.

Para criar conexões com Weber, Bronowski, Jakobson e Husserl/MerleauPonty, convém anotar as propostas de Leite Lopes sob três ângulos: a construção da ciência e o papel divulgador do cientista, a educatividade social para superar a dependência e a gerência do conhecimento científico. Embora se conectem, os três ângulos têm seus caminhos e percalços.

O físico nuclear reafirma que ciência e tecnologia devem desenvolver-se internamente aos países, sob parcerias "com todo o mundo" (Lopes, 1969, p.26), mas a favor dos interesses nacionais. Isso tanto significa o esforço em não perder cientistas por meio de sua adequada absorção quanto significa a exigência junto ao Estado para que grandes empresas abram laboratórios nos países subdesenvolvidos. Reconhece que o homem e a mulher de ciência não podem isentar-se de responsabilidade na construção de políticas científicas (o que costumam fazer em nome de verbas para seus projetos pessoais e corporativos). Nessa direção, as pessoas de ciência são coniventes com a ignorância, a fome e a miséria. Deixam de trabalhar pelo bem da humanidade, pelo que é comum a todos. Pior: deixam de ver que a "característica fundamental deste fim de século (sic!) é o fenômeno social, são as reivindicações que inapelavelmente fazem as populações em toda a parte e que não se conformam em passar fome ou viver na miséria..." (ibidem, p.66)

Veja-se que o discurso sobre os bens comuns - humanos - em Leite Lopes não se prende somente a mensagens científicas gerais, mas vai às "aplicações das tecnologias para o desenvolvimento econômico do País" (ibidem, p.40). Indispensável, também, é "ter acesso aos meios de produção do conhecimento científico e tecnológico" (ibidem, p.40). Aí se forma o campo semântico da libertação nessa época: o saber gerenciado a favor das maiorias, a ruptura com as dependências, a educação universal e de qualidade da criança e da juventude e o domínio dos meios de produção da ciência e da tecnologia. De modo pioneiro, o cientista propugna políticas integradas, embora somente as veja possíveis por meio de governos democráticos. Um excerto básico de seus textos o conecta ao pensamento socioeconômico da autonomia nacional e perfaz o movimento dos três ângulos de sua visão sociopolítica: 
Se não forem acompanhados por uma política nacional de desenvolvimento econômico intensivo, os programas educacionais darão lugar, em última análise, à emigração de cientistas e técnicos dos países menos desenvolvidos para os países avançados - paralelamente à exportação de matérias-primas (café, algodão, cacau, minérios de ferro) como base de sua economia. Programas e políticas de integração da economia com a educação, a cultura e a ciência só podem ser formulados por governos nacionais representativos das aspirações da maioria da população: a elevação constante de seu nível de vida juntamente com a afirmação de uma cultura nacional, integrada na cultura universal, mas sem perda de suas características e riquezas próprias. (ibidem, p.23)

Em capítulos de linguagem mais pessoal, o autor de Ciência e libertação anota uma fieira de percalços, seus e de colegas cientistas, para o estabelecimento de cursos e projetos de pesquisa. Constrangido, vê impossibilidade na construção de um moderno Instituto de Física no Rio de Janeiro, "pois não é possível estabelecer um tal Instituto na base do pessoal docente que já existe, com os salários que recebem, quando recebem, nem com regime de tempo de trabalho que deixa ocioso, na maior parte do dia, o Bloco da Cidade Universitária e suas salas de aula" (Lopes, 1969, p.170). Sistematicamente, compara a luta pela ciência no Brasil com o fomento científico nos Estados Unidos. A par dos milhões de dólares fomentados no país líder, relata que pedira à Capes e à Diretoria do Ensino Superior do MEC, no fim de 1967, recursos “até hoje não recebidos" (ibidem, p.170). Tratava-se de 150 mil cruzeiros novos. Pergunta: “Como, então, é possível realizar as aspirações mínimas dos estudantes?" (ibidem). De qualquer modo, o cientista e pensador não esmorece. Anota que cabe ao Estado financiar a pesquisa, porque os grandes plantéis industriais, filiais de organizações com sede nos países cientificamente avançados "não vêem por que motivo encorajar as pesquisas científicas 'nativas' pois se beneficiam diretamente dos conhecimentos científicos e tecnológicos dos países desenvolvidos”, e acrescenta que no caso de dar-se pesquisa financiada por empresas, ela é orientada para atividades específicas. Leite Lopes completa o seu pensamento sugerindo equilíbrio entre vetores: financiamento, valorização das pessoas de ciência e tecnologia, projeção do fazer científico sobre toda a vida social, construção de cultura e educação democráticas, diálogo com o mundo e aproveitamento da inteligência da juventude.

As negações ideológicas impostas por Weber ao cientista, bem como os limites da prevaricação pelo poder, quando se refere aos políticos, não estão plenamente ausentes do campo de sentidos de Leite Lopes, que batalha por um humanismo operante, centrado nas condições de uma sociedade invisível, que é a subdesenvolvida, evidentemente pela óptica dos nichos de poder mais prestigiados. Weber lamenta não poder dizer além do que vê, entre guerras, não tendo sido educado para nenhuma operação utópica. Husserl não negaria que "os modos do vivido, os atos e os correlatos dos atos" são uma espécie de prisão para a operação fenomenológica, que ele crê ser a novidade, a busca de transcendência. No entanto, essa transcendência é um conhecimento sem amar- 
ras. Não se trata de algo metafísico, pois, como aduz Merleau-Ponty, carece-se de superar a ilusão de que se sabe em si, pois é indispensável pensar "a partir do outro", o que enriquece nosso pensar. Justifica-se, pois, alguma utopia dos linguistas. Jakobson, ao lado de Lévi-Strauss, encontra certo outro, nada ilusório, existencial, não conhecido de antemão. Esse outro é o encontro histórico, no interior do interregno das guerras, dos pensamentos civilizado e primitivo. Desse encontro poderia nascer uma globalidade consciente de sua comunicabilidade, acima de preconceitos e pré-juizos. Uma nova linguagem, suporte de novas relações sociais. Uma existencialidade humanizada. Nova linguagem implica novos direitos. Relações radicais entre civilização e primitividade implicam gradações. Quase primitivos são os pobres metidos na ignorância, feitos reclusos nos grotões, fora dos direitos ao mercado dos produtos industriais, analfabetos ou, como mostrou Leite Lopes, simbolizados naquela única criança que, entre 1.400, conseguiu chegar ao curso superior brasileiro em 1966. A metáfora é plena.

O livro de Leite Lopes porta nova linguagem. Não aceita o real, pois esse é ilusão de sociedade democrática, com algum fomento à ciência, algum benefício ao mundo do trabalho, algum mercado, alguma educação, algum instituto de pesquisa. Esse real não produz nem humanismo, nem condição fenomenológica. Carece romper com ele. Os muitos outros estão à espera, prontos para o diálogo, ainda que próximos à primitividade. Bronowski dissera que não haveria astrofísica, história ou sequer linguagem se nós, os humanos, nos bastássemos em nossa solidão, em nosso ego. Se se deseja de fato dialogar internacionalmente; se o alvo é ampliar direitos; se há proposta de progresso e desenvolvimento, então os movimentos da inteligência passam por uma redução do espírito de ilusão (que supostas lideranças procuram impor), realizam uma ruptura na rotina do pensamento empoleirado na política das elites e apontam para a construção de uma consciência de liberdade, a única que pode gerenciar conhecimentos inovadores. No encontro com os outros, tornados invisíveis na história da desigualdade, constrói-se a transcendência do saber, indispensável quando se quer pensar de modo global. Vê-se, pois, que o espírito do tempo assim urdido ganha mais atualidade quando a consciência crítica provê saberes precisos, mas ecumênicos, não sectários, nem fundamentalistas. Diria Weber, repetindo, que estaria aí a necessária e rara atitude de "encarar de frente o severo destino do tempo presente".

\section{Administração e estranheza aparente}

Nada é tão precioso, na história do pensamento, que ver o texto e o contexto dos autores de certa área do saber. Uma das obras de referência para este ensaio é a coordenada por Bélanger \& Mercier (2006), da Universidade Laval, Quebec. Como citada, trata-se de Auteurs et textes classiques de la théorie des organisations. Entre os primeiros teóricos das organizações e da burocracia os coordenadores alinham Smith, Weber, Taylor, Fayol, Merton e Gouldner. O 
tempo sobre o qual incide o ensaio leva a escolher Merton (2006) e Gouldner (2006). Ambos tratam de burocracia e personalidade. Portanto, nada a ver com o debate deste ensaio. Engano. Os precursores da Universidade de Colúmbia tanto permitem fazer raciocínios opositivos quanto abrir seu pensamento e construir a nova área aplicada numa relação de texto/contexto. O texto de Merton inserto no Auteurs... é de 1949, e o de Gouldner, de 1959. O texto-testemunha de Merton, aqui cotado, embora organizado em coletânea mais tarde, é uma obra emblemática: A ambivalência sociológica (Merton, 1979). De Gouldner vem o texto forte, denominado La crisis de la sociologia occidental (Gouldner, 1970). Merton está preocupado com racismo, psiquiatria, família, casamento e liderança. Gouldner (2006, p.9) prefacia a obra com a imagem de que "se faz teoria entre o estrondo das armas de fogo", e dedica parte significativa do livro à crítica de Talcott Parsons.

Os textos de ambos sobre burocracia e personalidade estão um passo adiante das reflexões brasileiras citadas. Trata-se, antes de tudo, de escrever a partir de um lugar poderoso, vencedor, que começa a operar a divisão do mundo e a manobrar competências de filiação econômico-industrial pelo planeta afora. Tratam de buscar o entendimento de um sistema sociocultural do modo mais racional possível. Os textos de administração se voltam para o interior do lugar de onde se fala. Os textos de sociologia (visto que são educados como sociólogos) abrem-se para o diálogo com o Ocidente. Merton se baseia nas formulações de Max Weber e evidencia atitude muito crítica diante da burocracia. Segundo ele, a organização burocratizada realiza um "déplacement de buts par lequel une valeur instrumentale devient une valeur finale" (Merton, 2006, p.107) e, assim, torna-se um problema para a construção da personalidade. Faz brincadeiras com os homens de ciência submetidos à burocracia, que terminam sendo "separé de son équipement technique" (ibidem, p.105), como se o modo de constituição do laboratório fosse mais importante do que a capacidade inventiva e seus resultados. Como vai ocorrer com Gouldner, também Merton avança questões além de Weber. Para tanto, usa o leitmotiv da coletânea sociológica, a ambivalência. Afirma que Weber se interessa pela burocracia no que ela tem de preciso, eficaz, fiel. No entanto, aplicada à noção de ambivalência, ver-se-ia por outro ângulo, isto é, as estruturas organizacionais apresentariam limitações no atendimento desses objetivos. Gouldner começa pela discussão entre posturas de Weber e Saint Simon. Para um a organização moderna teria uma força liberadora. Para outro, a capacidade para destruir a personalidade das pessoas. Merton segue seu raciocínio pela apresentação de várias pistas de investigação. Termina o seu texto fazendo muitas perguntas que, segundo ele, estavam a exigir respostas. Destaca que a melhor compreensão de burocracia e personalidade levará ao entendimento da estrutura da sociedade, especialmente no encarar questões de domínio e submissão. As últimas palavras: "l'analyse fonctionelle des structures concrètes pourrait constituer un Temple de Salomon pour les sociologues" (Merton, 2006, p.111). Noutras palavras, tais estudos seriam a 
reconstrução simbólica da sociedade. Gouldner parte da dicotomia citada para outra: a burocracia como racionalidade e como natureza. O racional e o natural. Dois modelos. Um mecânico e outro baseado nas relações de composição e participação. Ao compará-los, não adota um ou outro, mas explica sua presença na vida de organizações americanas com que trabalhou. É rígido ao final do capítulo: "Cette dichotomie entre le modele rationnel et le modele du système naturel a tendance à occulter les orientations non rationnelles, traditionnelles du personnel de divection, et l'organisation informelle tend à etre examinée principalement chez le personnel des rangs inférieurs" (Gouldner, 2006, p.119). Trabalhando também com o discurso da ambivalência, busca as tensões organizacionais. Explica que, embora a autoridade na gestão moderna se fundamente na expertise, há conflitos entre conhecimento e experiência. Evidentemente a autoridade se define, em muitos casos, pela legislação, pela jurisprudência. No entanto, carece-se de avaliar responsabilidades e produzir confiança na relação entre subordinados e subordinadores. Outras tensões surgem: conhecimento e poder, o "de fora" e o "de dentro", capacidade e incapacidade no julgamento. Gouldner termina optando pela prática da "autonomia funcional”. Segundo ele, aí se supera o natural e o racional, pois haveria graus de interdependência e, assim, melhor estado de possível dependência entre pessoas da organização.

A tentativa de Gouldner de teorizar adequadamente no texto sobre Organizações é refletida na obra sociológica citada. Um capítulo exemplar é o da "Cultura utilitária y sociologia" (Gouldner, 2006, p.64-87). Depois de trabalhar sua origem e suas forças sociais, afirma que a cultura utilitária desconsidera a teoria. Desse modo "La ciência social de uma cultura utilitaria tiende siempre a un empirismo sin teoria, en el cual la conceptualización de los problemas es secundaria, mientras las energias son dedicadas a cuestiones de medición, diseño experimental o de investigación, muestreo o instrumentación". Interessa-lhe, pois, somente o resultado do uso. Merton, na obra motivada pelas ambivalências, tem um capítulo especial dedicado às ambivalências dos líderes, especialmente os "capitães da indústria americana". Depois de citar várias, chega a um ponto culminante do capítulo. Cita texto segundo o qual a lei de ferro da sociedade supostamente democrática consistia "no paradoxo aparente de que os líderes, inicialmente comprometidos com os valores democráticos, abandonavam esses valores quando sua atenção se voltava cada vez mais para a manutenção da organização e, especialmente, de seu próprio lugar dentro dela". (Merton, 2006, p.114). Critica a liderança empresarial na sua estreiteza econômica. Enquanto buscam equilíbrio mínimo entre empregados, consumidores e proprietários, esquecem-se das comunidades locais e de toda a sociedade. Segundo ele, o ambiente social da organização passa a ser determinante. O sucesso dos negócios não é fenômeno do indivíduo, mas da sociedade. Nessa direção, Merton vê o nascimento de uma sociedade emergente e autocrítica. Os líderes empresariais devem encarar a ambivalência entre lucrar e servir, realizando ambos os valores. Termina dizendo que a sociedade americana volta-se mais para seus defeitos, 
do mesmo modo como por muito tempo admirou seu poder. As lideranças não deveriam, enfim, permanecer na "periferia da grande transformação social de nossa época" (ibidem, p.123).

\section{Considerações finais}

Gouldner e Merton abrem espaços para a reflexão educativa, sociológica e científica latino-americana, ainda quando não pareça que o fazem. Visto que este ensaio não trabalha com a aritmética dos conteúdos, mas a capacidade que o texto-pensamento tem de compor o espírito do tempo, os sociólogos americanos que trataram de administração faziam, com seus instrumentos conceituais, $o$ que Schenberg e Leite Lopes desejavam: a crítica da organização. Mais: aqui se desejava que houvesse a organização, a racionalidade instituída e não a anomia, vácuo ideal para o poder colonizador. Enquanto no Brasil se propunha uma organização da cultura, que superasse os males republicanos e fizesse fluir direitos invisibilizados na história, na América se trabalha sobre a cultura da organização, a fim de que ela se alinhe na sociedade pretensamente democrática. Não se trata somente de dois momentos históricos, mas de duas batalhas do pensamento. Enquanto o esforço pela organização da cultura busca um salto de qualidade na história, o trabalho sobre a cultura da organização quer sedimentar conquistas e vê riscos a evitar. Daí a crítica contundente sobre liderança e poder, evidente nesses precursores da administração. Quando se liga texto/contexto, as obras teóricas de Merton e Gouldner criam mais fortes relações com o pensamento de Leite Lopes e demais cientistas-pensadores. A organização alinhada ao espírito do tempo (não é demais relembrar os escombros das guerras e os desafios da industrialização e das tecnologias) deveria rever sua cultura utilitária (no Brasil a incultura do mandonismo e do favor político), fomentar equilibradamente a ciência e a educação das novas gerações, rediscutir suas formas de liderança, redefinir o poder em face da globalização de riscos e possibilidades e equacionar o conflito entre lucro e serviço. De certo modo, a obra de Leite Lopes supõe a funcionalidade da organização, mas espera que ela inclua os muitos outros e outras da sociedade mitigada. Enfim, nesse quadro de nova linguagem e novo pensamento, espera-se um discurso que transcenda o real ilusório, que inclui o exclusivo individualismo e a estreiteza econômica, e encontre o mundo humano, ávido de valores e autonomia capazes de encarar e superar os fados.

O ensaio deve ousar, mas acima de tudo abrir-se... É o que se buscou fazer aqui, como contribuição ao pensar científico-filosófico sobre administração.

Notas

1 A publicação da ONU (Providing Global Public Goods, 2002) mostra que a nova transversalidade do bem-comum pode constituir-se como controle social da globalização, visto que estamos diante do avanço do conceito, da sua experimentação no cotidiano e 
de sua ampliação de territórios. Definido tradicionalmente como um bem irredutível à rivalidade e à exclusividade, cabe agora à nossa geração, aos viventes do mundo global e seus posteriores, disponibilizar os bens comuns ao uso, ao consumo e à fruição responsáveis de todas as pessoas. Eis a questão, mais que shakespeariana, pois o ser passa a implicar o compartilhar. A construção do bem comum não atemoriza, mas mexe e incomoda. Não é um fado, ou um fardo, mas sim um conjunto de possibilidades. Chomsky (2004, p.15-16) mostra que sua presença na vida das sociedades define o sentido de democracia, ou real e participativa, ou hipócrita, mera cortina de fumaça para as operações do poder corporativo desmedido. Quando os Protocolos de Kyoto, as chamadas Rodadas de Doha e os supostos encaminhamentos políticos de Bali e Davos não passam de cenário insosso para as performances do pastelão político, especialmente pela óptica dos mais ricos, entende-se melhor o tipo de sociedades ditas democráticas. Apesar disso, Chomsky, ao final de sua obra, coincide com Paulo Freire: o que aí está não é inelutável, ou irredutível. O difícil é precisamente o possível de fazer. Para tanto, concorrem a pesquisa aplicada, o ensino autonomizante, a dialogia social, a mobilização antimítica, a socialização dos meios de comunicação e sua avaliação constante, a construção de fato participativa de novas culturas políticas e de gestão nesses laboratórios sociais, que são as cidades e as universidades.

2 Introduzindo a obra Ruptures, Jean Galard (2002, p.12) anota que Celso Favaretto entende ruptura como "débuts d'une affirmation nationale qui reinvente son origine em refusant celle que la colonisation a engendrée...", o que ajuda a pensar o modernismo brasileiro (1922-1945) mas também mostra que Gaston Bachelard (Nouvel esprit scientifique), Alexandre Koyré (Études galiléeennes), Michel Foucault (L’archéologie du savoir) e Thomas Kuhn (La structure des révolutions scientifiques) entendem essa marca de descontinuidade, de certa negação em face do que parece hegemonizar o pensamento como ruptura, crise. Entendido o acúmulo no pensamento como repetição, redundância ou, pior, concordância com os modelos prestigiados, a ruptura é corte, descontinuidade a favor do novo, que será testado e julgado na seqüência dos novos movimentos do pensar.

3 A famosa canção americana pode ser traduzida por: "És ou não és minha garota?".

4 De fato, Walter Benjamin (1985, p.112) defendia posições que agradariam a Weber. Para ele, "a linguagem seria a mais alta aplicação da faculdade mimética; um médium em que as faculdades primitivas de percepção do semelhante penetraram tão completamente, que ela se converteu no médium em que as coisas se encontram e se relacionam, não diretamente como antes, no espírito do vidente ou do sacerdote, mas em suas essências, nas substâncias mais fugazes e delicadas, nos próprios aromas. Em outras palavras: a clarividência confiou à escrita e à linguagem as suas antigas forças, no correr da história”. No fundo, Benjamin estava garantindo às pessoas de pensamento do presente o direito de construção, pela linguagem, dos mais profundos dons, antes vividos no ritual religioso. $\mathrm{O}$ esclarecimento, ou a ruptura epistemológica, ainda estava presente na linguagem, nas relações de sentido.

$5 \mathrm{O}$ professor J. Leite Lopes ensinou física teórica na Universidade Federal do Rio de Janeiro. Acompanhou a criação do CNPq e da Capes e participou do seu desenvolvimento. Trabalhou na Faculdade de Ciências de Paris e foi companheiro de pesquisas de Oppenheimer, em Princeton. Sofreu e batalhou a favor da criação de Institutos de Altos Estudos, do fomento público para a ciência e do desenvolvimento de universidades comprometidas com a pesquisa e a melhor educação da juventude. Leite Lopes 
foi um ser braçal na construção da ciência brasileira, o que se depreende de sua correspondência, sua busca de livros científicos, o trabalho por criar a mínima estrutura para núcleos de pesquisa e o esforço quase heroico para a formação de quadros na incipiente construção do conhecimento democrático no Brasil.

Referências

AZEVEDO, F. Cultura brasileira. Brasília: UnB, 1963.

Na batalha do humanismo. 2.ed. São Paulo: Melhoramentos, 1967.

BÉLANGER, L. ; MERCIER, J. Auteurs et textes classiques de la théorie des organisations. Québec: Les Presses de l’Université Laval, 2006.

BENJAMIN, W. Magia e técnica, arte e politica. São Paulo: Brasiliense, 1985.

BRONOWSKI, J. Ciência e valores humanos. Belo Horizonte: Itatiaia; São Paulo: Editora da USP, 1979.

CASSÉ, M.; MORIN, E. Filhos do céu. Entre vazio, luz e matéria. Rio de Janeiro: Bertrand Brasil, 2008.

CHOMSKY, N. El lenguaje y el entendimiento. Barcelona: Seix Barral, 1973.

. Il bene comune. Casale Monferrato: Edizioni Piemme, 2004.

FERRI, M. G.; MOTOYAMA, S. (Coord.) História das ciências no Brasil. São Paulo: EPU, Editora da USP, 1979.

FURTADO, C. Sete teses sobre a cultura brasileira. Que somos? Revista do Brasil, Rio de Janeiro, ano 1, n.2, 1984 .

Globalização das estruturas econômicas e identidade nacional. Estudos Avançados, São Paulo, v.6, n.16, set./dez. 1992.

GALARD, J. (Ed.) Ruptures. De la discontinuité dans la vie artistique. Paris: Louvre ; École Nationale Supérieure des Beaux-Arts, 2002.

GOULDNER, A. W. La crisis de la sociología occidental. Buenos Aires: Amorrortu, 1970 .

De l'analyse des organisations. In: BÉLANGER, L. ; MERCIER, J. Auteurs et textes classiques de la théorie des organisations. Québec: Les Presses de l'Université Laval, 2006.

GUERREIRO RAMOS A. Introdução crítica à sociologia brasileira. Rio de Janeiro: Editorial Andes Limitada, 1957.

JAKOBSON, R. Relações entre a ciência da linguagem e as outras ciências. Lisboa: Livraria Bertrand, 1974.

LACOSTE, J. A filosofia no século XX. 2.ed. Campinas: Papirus, 1998.

LÉVI-STRAUSS, C. Anthropologie structurale. Paris: s. n., 1958.

LOPES, J. L. Ciência e libertação. Rio de Janeiro: Paz e Terra, 1969.

MERTON, R. K. A ambivalência sociológica e outros ensaios. Rio de Janeiro: Zahar Editores, 1979. 
MERTON, R. K. Structure bureaucratique et personnalité. In: BÉLANGER, L.; MERCIER, J. Auteurs et textes classiques de la théorie des organisations. Québec: Les Presses de l'Université Laval, 2006.

MORIN, E.; CASSÉ, M. Filhos do céu. Entre vazio, luz e matéria. Rio de Janeiro: Bertrand Brasil, 2008.

MURARO, R. M. A automação e o futuro do homem. Petrópolis: Vozes, 1968.

PROVIDING GLOBAL PUBLIC GOODS. New York: ONU, 2002.

REVISTA PAZ E TERRA. Rio de Janeiro, ano II, n.8, set. 1968.

ROSSI-LANDI, F. Il linguaggio come lavore e come mercato. Milano: Bompiani, 1968.

SARTRE, J.-P.; FERREIRA, V. O existencialismo é um humanismo. 3.ed. Lisboa: Editorial Presença, 1971.

SCHENBERG, M. Tecnologia e subdesenvolvimento. Paz e Terra. Rio de Janeiro: Editora Civilização Brasileira, número 8, ano II, setembro 1968.

SCHWARZ, R. Fim de século. Incompleto, o processo de modernização provou ser ilusório. Folha de S.Paulo, 4 de dezembro de 1994.

VISIONE UNIVERSALE. Alla ricerca dello spazio perduto. Il Sole 24 ore. Milano, n.157, giovedì, 22 gennaio 2009.

WEBER, M. Ciência e politica. Duas Vocações. São Paulo: Martin Claret, 2002.

RESUMO - No tempo de novas tramas tecnológicas e riscos globais, o pensamento científico elaborado na experiência brasileira celebra um texto memorável de pouco mais de 40 anos: Ciência e libertação, do físico nuclear J. Leite Lopes. O presente ensaio perscruta esse pensamento, que se comunica com a crítica científica horrorizada com os escombros do pós-guerra e se projeta numa visão de ruptura epistemológica em vista da realidade social. Tal movimento de política científica se converte em proposta de gestão do conhecimento. A atitude metodológica deste ensaio busca textos que testemunham o entre e o pós-guerra do século XX e em contribuições das ciências da natureza e da cultura dirigidos à construção da sociedade democrática. A obra de Leite Lopes reside aí, como um feixe de linguagens a serviço da mudança social e do efetivo desenvolvimento do Brasil e da América Latina.

PALAVRAS-CHAVE: Ciência e libertação, Ruptura, Pensamento científico, Sociedade democrática.

ABSTRACT - At the time of new technological schemes and global risks, scientific thinking developed in the Brazilian experience celebrates a memorable text of little more than 40 years: Science and Liberation, written by the nuclear physicist J. Leite Lopes. This paper investigates this thought, which communicates with the critical scientific horrified by the rubble of postwar and design a vision of epistemological rupture in view of social reality. This movement becomes a proposal for a management of knowledge. The methodological approach of this essay seeks texts that bear witness to and from 
post-war twentieth century, and contributions from the natural sciences and culture aimed at building a democratic society. The work of Leite Lopes lies there like a bunch of languages in the service of social change and the effective development of Brazil and Latin America.

KEYWORDS: Science and liberation, Rupture, Scientific thinking, Democratic society.

Luiz Roberto Alves é coordenador do Programa de Pós-Graduação Stricto Sensu em Administração da Universidade Metodista de São Paulo. @ - luiz.alves@metodista.br Recebido em 6.12.2010 e aceito em 4.05.2011. 